NEW: Emerging Scholars in Australian Indigenous Studies

\title{
Site Visit to La Perouse
}

\section{Eleanor Brus}

University of Technology Sydney, Faculty of Arts and Social Sciences, PO Box 123, Ultimo NSW 2017, Australia. eleanor.m.brus@student.uts.edu.au

\section{DOI: $\underline{\text { https://doi.org/10.5130/nesais.v4i1.1516 }}$}

"When you walk here today, you walk among the spirits of our ancestors," reads a brand-new Welcome To Country sign above the front desk of the La Perouse Museum, the text an evocative reminder of the resilience of Indigenous Australians in places where they have struggled for a voice. While this demonstrates a shift in recent years to acknowledging and valuing the Indigenous heritage of these places, an exploration of the museum makes the precedence given to eponymous explorer Lapérouse clear. This is a place where the French community has long celebrated their own place in Australia. However, despite their tens of thousands of years in the area, the addition of Aboriginal history is a recent one. If Aboriginal history can be considered a battlefield of conflicting accounts and perspectives, then the exhibits in this museum are the survivors of a long war.

The small room dedicated to the area's Aboriginal history is separate and self-contained, much like the little island featured in the Welcome sign. This nondescript island off the La Perouse headland does not have a particularly exciting name; Cook passed it by whilst discovering things the local population had known about for millennia and declared it "a small bare island" - a name that stuck (Office of Environment and Heritage 2018). Bare Island now hosts a late-nineteenth century fort, and features a long wooden bridge one must cross in order to explore its concrete bunker passageways and grassy knolls. A twelve-tonne cannon points threateningly towards the open sea, repelling once-time invaders. It is unlikely that those colonial architects considered themselves to be invaders of this land.

On Sunday April 8th, this small bastion was occupied by the Blak Markets, a gathering of Indigenous crafts and culture, the Aboriginal flag flying at the centre of the fort. The long history of Aboriginal craft in the area is highlighted in the museum, and it is interesting to note the blending of European and Indigenous worlds. A piece of shell art forms the arch of the Harbour Bridge, and poignantly, another one reads 'Home'. A particularly fine pair of thongs can be purchased from a remote Northern Territory Indigenous art community, sturdy footwear for the continued exploration of the rocky foreshore.

Standing at the top of the headland by the looming, pointed monument to Lapérouse, one can imagine the tall ships as they sailed into the homeland of the Muru-ora-dial clan. There is no monument to Aboriginal history here, but the small island and the shape of the coastline is eternal, and so, therefore, must be its people. 


\section{References}

Office of Environment and Heritage 2018, Bare Island Fort, NSW Government, Canberra, viewed 13 April 2018,

$<$ http://www.environment.nsw.gov.au/heritageapp/ViewHeritageItemDetails.aspx?id=5045621>.

(c) (1) (C) 2018 by the author(s). This article is distributed under the terms and conditions of the Creative Commons Attribution license (http://creativecommons.org/licenses/by-nd/4.0/). 